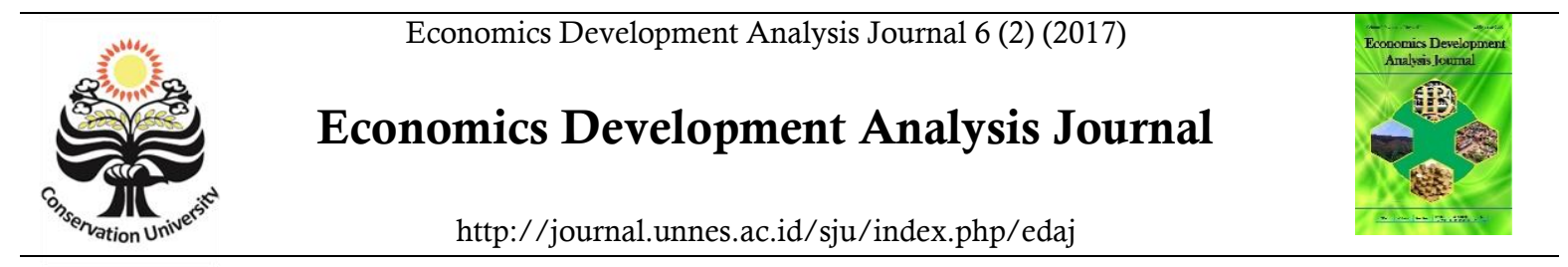

\title{
Increasing Competitiveness Strategy Bobung Wooden Batik Center With Krebet Wooden Batik as Tourism Support
}

\section{Dwiyanti $^{1 凶}$}

Economics Development Department, Economics Faculty, Universitas Negeri Semarang

\begin{tabular}{|c|c|}
\hline Article Info & Abstract \\
\hline $\begin{array}{l}\text { Article History: } \\
\text { Received January } 2017 \\
\text { Accepted March2017 } \\
\text { Published May } 2017\end{array}$ & $\begin{array}{l}\text { Competition between the centers is caused by the differences between the two centers. The research } \\
\text { is analysis strategy of competitiveness increase of a study of Bobung Wooden Batik Craft Center and } \\
\text { Krebet Wooden Batik Craft Center. The aim of this research is to describe, analyze the internal and } \\
\text { external factors inside the centers, and formulate the right strategy to increase the competitiveness } \\
\text { between the two centers. The method is SWOT analysis method and the IE matrix. The population }\end{array}$ \\
\hline $\begin{array}{l}\text { Keywords: } \\
\text { SWOT Analysis, IE Matrix } \\
\text { SME of Batik Craft }\end{array}$ & $\begin{array}{l}\text { used for this research are SME entrepreneurs of wooden batik handicraft, which include eighteen } \\
\text { entrepreneurs of wooden batik handicraft of Krebet center and thirteen entrepreneurs of Bobung } \\
\text { center. Based on the identification, the main strength of wooden batik handicraft is the product } \\
\text { innovation of the design and shape. Based on the analysis, the main opportunity is the increasing } \\
\text { number of visitors and the main threat of it is the substitute product. The alternative formulation of } \\
\text { strategy using the SWOT matrix produces the main strategic alternative that is the SO strategy to } \\
\text { reach the existing opportunity by utilizing the strength owned that is the product innovation. The } \\
\text { formulation based on IE matrix produces the main strategy that is the growth strategy. }\end{array}$ \\
\hline
\end{tabular}




\section{INTRODUCTION}

The Indonesian government now is favoring the tourism sector as one sector that greatly contributes to the country's foreign exchange. Tourism is one of the most climatesensitive economic sectors, but also a contibutor to climate change (Michailidou, et al, 2016). The government's seriousness is realized in the Visit Indonesia program since 2008 to increase the number of tourist visits to Indonesia. Then in 2009 until 2013 it is proclaimed as a continuation of the program in each tourist destination. Tourism is a new industry in providing the

Description : The number is in trillion rupiahs except the work force that is in million people the share in percentage (\%)

The Special Province of Yogyakarta is a province that sells many tourist objects in the following: there is a historical tour with some historical heritage in the colonial era; there is a natural tourism found in the southern region of D.I Yogyakarta. Geographically there are some beaches in the southern part besides there are also the arts and cultural tourism and the regional culinary. To measure tourism sustainability requires a knowledge of the complexity of tourism systems and the specifics of any given location (Franzoni, 2015).

The development of tourism in the Regency / City of Indonesia, especially the Province of D.I Yogyakarta has progressed very rapidly whether in terms of quality or quantity. This can be seen from the growing and increasing facilities and infrastructure of the tourism supporters. Yogyakarta Special Region as a tourist destination also has the cultural diversity and the natural beauty that can attract more tourists to come. The destination is not only focused on Yogyakarta City, but is also spread in every Regency / City in D.I Yogyakarta.

The development of tourism in the Province of D.I Yogyakarta gives a positive impact on tourism in the Regency / City with many new tourist destinations. The potentiality of each regency / city in Yogyakarta is very varied ranging from culinary, handicrafts, arts, employment, increasing the income, even in providing the rapid economic growth. Besides, the tourism sector also contributes enough to the national income as well as the local revenue.

The developing tourism will also have a positive impact on the innovation of tourism support sectors in each tourist area that later will increase the income of the surrounding society. Tourism trend on work force in tourism industry increases every year from $6.87 \%$ in 2010 to reach $9.00 \%$ in 2014 . The substantial contribute on to GDP should be developed further as a driving force for other economic sectors in each region as the local superior.

and culture. Tourism development efforts allow for the development of the Small and Medium Micro Enterprises (SMEs) with various advantages that can be developed.

The SMEs are expected to continue growing and competing so that in the future it can obtain the economy based on the populist economy, which is an economic system based on people's economic power. Populist Economy itself is an economic activity or business conducted by most people (popular) with selfmanaging economic resources that can be tried and dominated, later it is called Small and Medium Micro Enterprises (Hariyadi).

One of the SMEs which potentiality can be developed is wooden batik handicrafts located in Bobung Village, Patuk Sub-District, Gunungkidul Regency. Batik is one of the original handicrafts of Indonesia that has a specific style as a reflection of the national cultural wealth of Indonesia (Bonita, 2013). Wooden batik handicrafts located in Bobung, Gunungkidul is not the only one in the province of D.I. Yogyakarta. Similar wooden batik handicraft is also available in Krebet Village, Bantul. The competition between the two similar wooden batik handicraft centers then must be handled with the right strategies in order not to lose in competing with other entrepreneurs who are in the similar center.

The study of this research is the commodity of wooden batik handicrafts in the province of D.I.Yogyakarta. Wooden batik 
handicraft itself is the art of batik on wood carving. This handicraft has become one of the tourist destination in DIY. The famous wooden batik center is located in Krebet Village, although similar centers exist in Bobung Village. Both centers produce the same wooden batik products. However, there are distinct advantages between the two centers so have their respective enthusiasts. This similarity of production results in the emergence of competitiveness in both centers.

Strategy analysis needs to be conducted to improve the competitiveness in both centers. The fundamental reason to do the strategy analysis is to know the advantages and weaknesses of each center in an effort to increase the competitiveness, so that later it can give input for the development of the center for better. Tourism sectors participate differently in social networks (Viren, et al, 2015). Based on the background of the problem, the formulation of the problem in this research is "How is the Strategy of Increasing Competitiveness of Bobung Wooden Batik Center and Krebet Wooden Batik Center?" The aim of this research is to know the strategy to improve the competitiveness of both centers as the development of SMEs in supporting the tourism.

\section{RESEARCH METHOD}

The method used in this research is mixed method by using the primary and secondary data related to Bobung and Krebet wooden batik centers. The sampling technique uses purposive sampling. Purposive sampling is also called judgment sampling, which is a carefully selected sample by taking selective people or object of research and has specific characteristics (Sugiyono, 2010) Purposive Sampling technique takes thirteen respondents from Bobung Center and eighteen respondents from Krebet Center. The analysis used to determine the strategy is the SWOT analysis.

\section{RESULTS AND DISCUSSION}

Environmental analysis is one of the processes that must be implemented in the strategic management that aims at identifying the environment of wooden batik handicraft center in Bobung, Gunungkidul Regency, and of wooden batik handicraft in Krebet, Bantul. This SME Environment consists of the internal environment and external environment.

Internal Environment, Internal environmental analysis is conducted by reviewing the factors contained within the center of wooden batik to identify and evaluate the trends within the business. This analysis focuses on obtaining the key factors those are the strengths and weaknesses of the center for improving the competitiveness. The center of wooden batik handicrafts in Gunungkidul and Bantul regencies can utilize the strengths and overcome the existing weaknesses based on the analysis results. The internal factors owned include the aspects of management, marketing, finance, production or operations, and human resources.

External Environment, analysis of the external environment of wooden batik craft center of Bobung Gunungkidul and of Krebet Bantul is conducted by reviewing the external factors of the effort to identify the trends that are out of control of the running business and it usually changes faster. This analysis focuses on obtaining the information on the key factors that become the main opportunities and threats faced by the wooden batik craft center of Bobung Gunungkidul and Krebet Bantul. Some external factors give a direct effect and some give an indirect effect on the center. The external factors can be divided into five strengths those are the economy, social, cultural, demographic, and environmental issues; politics, government, and law, technology and environmental centers.

Strategy for Increasing the Competitiveness of Wooden Batik Center of Bobung and Krebet, based on the results of internal environmental analysis, there are several factors obtained in the form of strengths and weaknesses that affect the wooden batik center. The internal strategic factors that become the strengths for the wooden batik center is:

1) The existence of work specialization

2) The quality of product has been in accordance 
with the consumer's taste

3) The workforce is close to the business location

4) The ease of access to the raw materials

5) The existence of product (form) innovation

6) The skilled and experienced labors

While the internal strategic factors that become the weakness for the wooden batik center is:

1) The lack of promotional media

2) The access to the quite difficult location

Based on the identification of the internal strategic factors, the IFAS matrix was then compiled and weighted then ranked on each variable of strength and weakness. After getting the weight and the average rating of each variable, it can find the weight of the average score of each variable. Based on the average weight score of each variable, it can find the main strength and weakness of wooden batik craft center of Bobung and Krebet.

Based on Table 2 containing the results of the respondents' opinion on the internal strategic factors, the main strengths for wooden batik business in Gunungkidul Regency are the specialization of work and the skilled and experienced workers with the average weight scores of 0.594 and 0.592 . The internal strategic factors have the highest average weight and the highest average rating for the strength variable. It means, the respondent considers that the factors are the most important strength compared to other strength factors and are also the major strength for the small businesses. The main weakness for wooden batik handicraft business in Gunungkidul is the access to the difficult location with an average weight score of 0.191 in which the weight of the average score is the highest for the weakness variable. However, overall, based on the final IFAS matrix analysis results, the weighted average total score of the IFAS matrix was 3.611 consisting of the total weight of the average score of the strength of 3.268 and the weakness of 0.343 . This shows that the internal position of the wooden batik handicraft business is above the average in the whole internal strength, which is above 2.5 . It can be concluded that the business of Bobung wooden batik handicraft in Gunungkidul is able to utilize the strengths owned and able to overcome the existing weaknesses

Table 2. Analysis of IFAS Matrix of Bobung Wooden Batik Handicraft Center

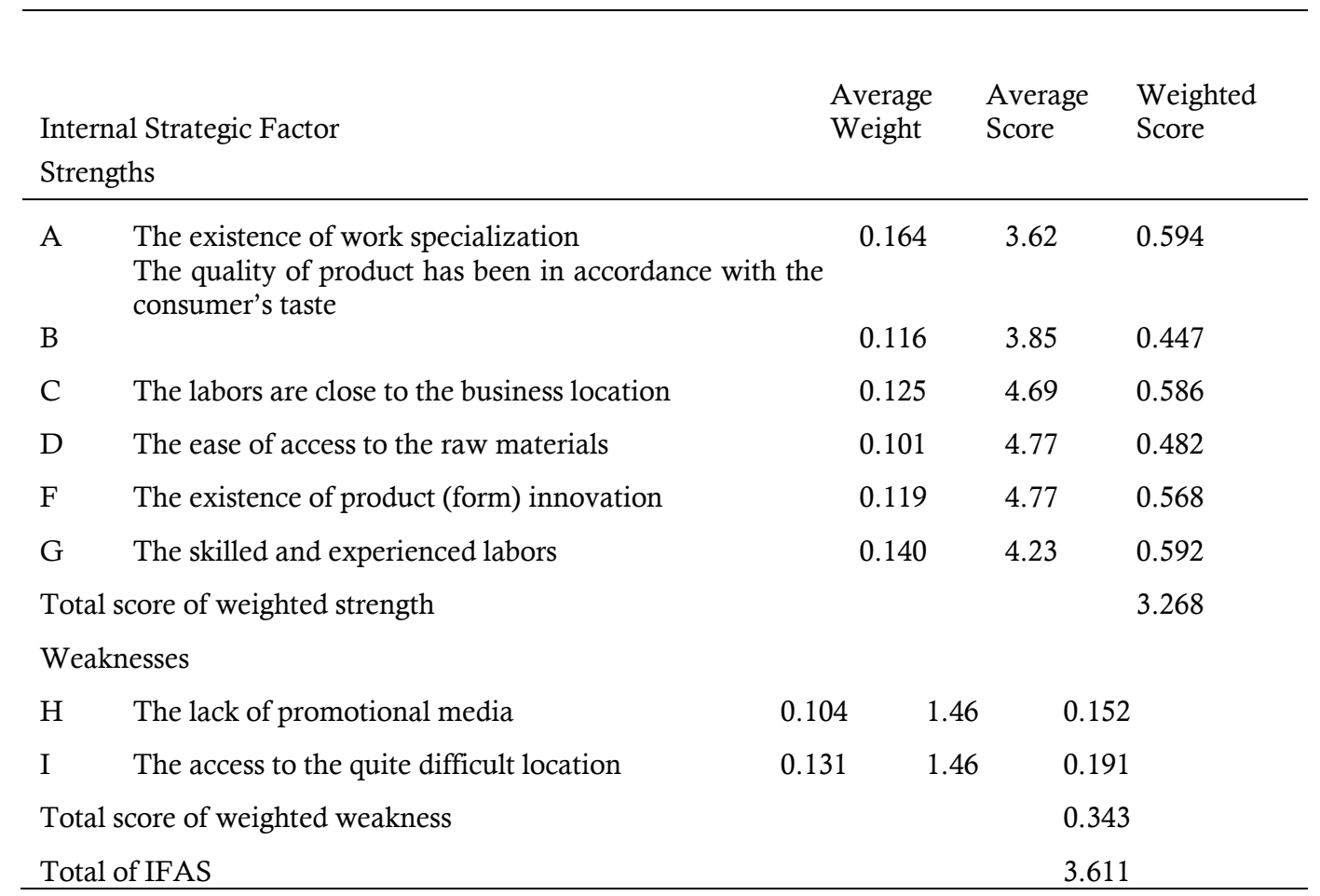


Based on Table 2 containing the results of the respondents' opinion on the internal strategic factors, the main strengths for wooden batik business in Gunungkidul Regency are the specialization of work and the skilled and experienced workers with the average weight scores of 0.594 and 0.592 . The internal strategic factors have the highest average weight and the highest average rating for the strength variable. It means, the respondent considers that the factors are the most important strength compared to other strength factors and are also the major strength for the small businesses. The main weakness for wooden batik handicraft business in Gunungkidul is the access to the difficult location with an average weight score of 0.191 in which the weight of the average score is the highest for the weakness variable. However, overall, based on the final IFAS matrix analysis results, the weighted average total score of the IFAS matrix was 3.611 consisting of the total weight of the average score of the strength of 3.268 and the weakness of 0.343 . This shows that the internal position of the wooden batik handicraft business is above the average in the whole internal strength, which is above 2.5. It can be concluded that the business of Bobung wooden batik handicraft in Gunungkidul is able to utilize the strengths owned and able to overcome the existing weaknesses.

Based on Table 3 of the respondent's assessment of the external strategic factors, the main opportunity for wooden batik business is the provision of training service from the related offices with an average weight score of 0.569 , in which the weight of the average score is the highest for the opportunity variable. The external strategic factor has the highest average weight. It means the respondents consider that the factor is the most important one among the other external factors. While the main threat faced by Bobung wooden batik business is the difficulty of labor regeneration with the weight of the average score of 0.492 , in which the weight of the average score is the highest for the threat variable. The total of weighted average score of the EFAS matrix is 3.626 , which consists of the total weight of the average score of opportunity of 2.230 and of threat of 1.396 .

Table 3. Analysis of EFAS Matrix of Bobung Wooden Batik Handicraft Center

\begin{tabular}{|c|c|c|c|c|}
\hline \multicolumn{2}{|c|}{ External Strategic Factor } & $\begin{array}{l}\text { Average } \\
\text { Weight }\end{array}$ & $\begin{array}{l}\text { Average } \\
\text { Weight }\end{array}$ & $\begin{array}{l}\text { Weighted } \\
\text { Score }\end{array}$ \\
\hline \multicolumn{5}{|c|}{ Opportunities } \\
\hline A & The supporting economic condition & 0.151 & 3.69 & 0.557 \\
\hline B & The increasing tourist number & 0.155 & 3.62 & 0.561 \\
\hline C & The more modern technology & 0.147 & 3.69 & 0.542 \\
\hline $\mathrm{D}$ & $\begin{array}{l}\text { The provision of training service from the } \\
\text { related offices }\end{array}$ & 0.151 & 3.77 & 0.569 \\
\hline \multicolumn{2}{|c|}{ Total of weighted score of opportunity } & & & 2.230 \\
\hline \multicolumn{5}{|c|}{ Threats } \\
\hline $\mathrm{E}$ & The existence of substitution product & 0.131 & 3.62 & 0.474 \\
\hline $\mathrm{F}$ & The difficulty of labor regeneration & 0.139 & 3.54 & 0.492 \\
\hline G & $\begin{array}{l}\text { The existence of competitors from other } \\
\text { regions }\end{array}$ & 0.127 & 3.38 & 0.429 \\
\hline \multicolumn{2}{|c|}{ Total of weighted score of threat } & & & 1.396 \\
\hline \multicolumn{2}{|c|}{ Total of EFAS } & & & 3.626 \\
\hline
\end{tabular}


Table 4. IFAS Matrix of Wooden Batik Handicraft Business of Krebet, Bantul

\begin{tabular}{|c|c|c|c|c|}
\hline & Internal Strategic Factors & $\begin{array}{l}\text { Average } \\
\text { Weight }\end{array}$ & $\begin{array}{l}\text { Average } \\
\text { Score }\end{array}$ & $\begin{array}{l}\text { Weighted } \\
\text { Score }\end{array}$ \\
\hline & Strengths & & & \\
\hline A & $\begin{array}{l}\text { The existence of work specialization } \\
\text { The quality of product has been in } \\
\text { accordance with the consumer's taste }\end{array}$ & 0.14 & 3.33 & 0.466 \\
\hline B & & 0.097 & 3.56 & 0.345 \\
\hline $\mathrm{C}$ & $\begin{array}{l}\text { The labors are close to the business } \\
\text { location }\end{array}$ & 0.4 & 3.5 & 1.400 \\
\hline $\mathrm{D}$ & $\begin{array}{l}\text { The ease of access to the raw materials } \\
\text { The existence of product (form) }\end{array}$ & 0.099 & 3.5 & 0.347 \\
\hline $\mathrm{E}$ & innovation & 0.106 & 3.56 & 0.377 \\
\hline \multirow[t]{3}{*}{$\mathrm{F}$} & The skilled and experienced labors & 0.113 & 3.5 & 0.396 \\
\hline & Total score of weighted strength & & & 3.331 \\
\hline & Weaknesses & & & \\
\hline G & The lack of promotional media & 0.104 & 1.28 & 0.133 \\
\hline $\mathrm{H}$ & The difficulty to add the business capital & 0.111 & 1.33 & 0.148 \\
\hline \multirow[t]{3}{*}{ I } & The location that is difficult to reach & 0.113 & 1.44 & 0.163 \\
\hline & Total score of weighted weakness & & & 0.443 \\
\hline & Total of IFAS & & & 3.774 \\
\hline
\end{tabular}

Based on Table 4, the respondents' opinion on the internal strategic factors, the main strength for the wooden batik business in Bantul Regency is the labors that are close to the location with an average weight score of 1.400 . The internal strategic factor has the average weight and the highest average rating for the strength variable. It means that the respondent considers that the factor is the most important strength compared to other strength factors and is also the major force for the small businesses. The main weakness for wooden batik business in Bantul is that it is a difficult location to reach with an average score of 0.163 in which the weight of the average score is highest for the weakness variable. However, overall, based on the final results of IFAS matrix analysis, the total weighted average score of the IFAS matrix is 3.774 that consists of the total weight of the average strength score of 3.331 and the weakness of 0.443 .
Based on Table 5 of the respondents' assessment of the external strategic factors, the main opportunity for wooden batik business is the provision of training services from related offices with a weighted score of 0.599 in which the weight of the average score is the highest for the opportunity variable. The external strategic factor has the highest average weight. It means that the respondents consider that it is the most important factor than other external strategic ones. While the main threat faced by Krebet wooden batik business is the raw material fluctuation with weight average score of 0.960 in which the weight of average score is the highest for the threat variable.

The result of SWOT analysis shows that the centers of Bobung and Krebet are in quadrant I. The strategy recommendation that can be given is aggressive strategy, which is applied through the growth strategy. 
Table 5. EFAS Table of Wooden Batik Handicraft Business of Krebet, Bantul

\begin{tabular}{|c|c|c|c|c|}
\hline & External Strategic Factors & $\begin{array}{l}\text { Averag } \\
\text { e } \\
\text { Weight }\end{array}$ & $\begin{array}{l}\text { Averag } \\
\text { e Score }\end{array}$ & $\begin{array}{l}\text { Weighte } \\
\text { d Score }\end{array}$ \\
\hline & Opportunities & & & \\
\hline $\mathrm{A}$ & The supporting economic condition & 0.143 & 3.56 & 0.509 \\
\hline B & The increasing tourist number & 0.119 & 3.72 & 0.443 \\
\hline $\mathrm{C}$ & The more modern technology & 0.125 & 3.67 & 0.459 \\
\hline \multirow[t]{3}{*}{$\mathrm{D}$} & $\begin{array}{l}\text { The provision of training service from the } \\
\text { related offices }\end{array}$ & 0.161 & 3.72 & 0.599 \\
\hline & Total score of weighted opportunity & & & 2.009 \\
\hline & Threats & & & \\
\hline $\mathrm{E}$ & $\begin{array}{l}\text { The fluctuation of raw material and } \\
\text { supporting one }\end{array}$ & 0.353 & 2.72 & 0.960 \\
\hline $\mathrm{F}$ & The provision of substitution product & 0.113 & 2.72 & 0.307 \\
\hline G & $\begin{array}{l}\text { The existence of the similar competitors } \\
\text { from other regions }\end{array}$ & 0.134 & 2.44 & 0.327 \\
\hline \multirow[t]{3}{*}{$\mathrm{H}$} & The productive labor regeneration & 0.119 & 2.56 & 0.305 \\
\hline & Total score of weighted threat & & & 1.899 \\
\hline & Total of EFAS & & & 3.909 \\
\hline
\end{tabular}

Factors Affecting the Development of Wooden Batik Centers of Bobung and Krebet

Wooden batik center is one of small and medium enterprise group in producing the wooden batik handicraft that contributes enough in the economy of the Province of D.I Yogyakarta. Batik business incorporated in the center has the potentiality in absorbing the workforce and reducing the unemployment, especially in Bobung and Krebet Villages.

The factors affecting the development of wooden batik business incorporated in the center are in the internal and external environment. Internal environment is a reflection of the strengths and weaknesses of a business organization and may reflect the managerial ability to manage the business. It can show the managerial ability to manage the business. It can show the power of human resources, which covers all material and non-material aspects. There are five variables of the internal factors in this research as follows: management, raw materials, labor, technology, and marketing.
After analyzed, the five variables have a large percentage in influencing the development of wooden batik business of Bobung and Krebet. These variables then become the strengths and weaknesses to determine the right strategy to increase the business competitiveness of wooden batik Bobung and Krebet.

External environment is a condition of a company that can affect the development in running its business. There are four variables of the external factors as follows: economic conditions, social culture, government support, competitors and market share. All the external environment variables are analyzed which results have influence and can be the opportunity and threat for the development of wooden batik business of Bobung and Krebet that are incorporated in the center.

The Strength of Wooden Batik Centers of Bobung and Krebet, the determination of the strength factors from the internal environment is based on the initial research that is through questionnaires and interviews with the owner of 
wooden batik business incorporated in the centers of Bobung and Krebet. Then the data processing is conducted by ranking and weighting the data based on the results obtained about the strength of the wooden batik business incorporated in the center.

The strength aspect is obtained in wooden batik business in Bobung Village with the indicator factor that Bobung wooden batik has a specialization of work with a weighted score of 0.594. It shows that wooden batik business of Bobung Village incorporated in the center has a specialization of work in making the product well.

The strength aspect is obtained in wooden batik business in Krebet Village with the indicator factor that it has the labors that are close to the business location with a weighted score of 1.400. The labors that are close to the business location is very beneficial either for the entrepreneurs or the surrounding community. The availability of labors that are close to the business location can reduce the production costs.

The Weakness of Wooden Batik Centers of Bobung and Krebet, the weakness of wooden batik business found in Bobung Village and Krebet Village is the difficult access to the location with the weighted score of 0.191 and 0.163 . The difficult access to the location allows the consumers to prefer alternatives / substitutes for the similar products that can reduce the sales. The difficult access to the location also makes the product less familiar to the society and the tourists. It requires the provision of public transportation that reaches the location of the two centers.

The Opportunity of Wooden Batik Centers of Bobung and Krebet, the determination of the strength factor from the external environment based on the initial research is used to determine the opportunity and threat factor to the wooden batik business. Furthermore, the data processing is conducted by ranking and weighting from the data obtained.

The opportunity owned by batik businesses incorporated in wooden batik center of Bobung and Krebet is the provision of training service from the related offices with a weighted score of 0.569 and 0.599 . With the provision of training service from the related offices, it is expected that the employers and labors will be more creative and innovative to develop the products and marketing in order to enhance their competitiveness.

The Threat of Wooden Batik Centers of Bobung and Krebet, the indicator factor that is the difficulty of labor regeneration becomes the biggest threat to wooden batik in Bobung Village. It obtains a weighted score of 0.492. The productive aged labors in Bobung Village prefer to work outside the area because they see that working in factories or in other areas can increase their income more. If this occurs continuously, the production of Bobung wooden batik will be decreased.

The indicator factor that is the fluctuation of raw material and the supporting one become the biggest threat for wooden batik in Krebet Village with a weighted score of 0.960 . The frequent increase in raw material prices occurs because the raw material inventories are decreasing in the market and also because of the increase in prices in general. The increase in the raw materials makes the entrepreneurs confused to raise the selling price of their products.

The Factors Affecting the Center Competitiveness

The dimensions in the diamond porter model are based on the factors of demand corporate strategy, and competition, and the most influential factor is the government on the development and growth of the center.

The condition factor that becomes the competitiveness of Bobung and Krebet centers are as follows:

Human resources are required in meeting the needs of labors in the process of production of wooden batik. The labors owned by both centers come from the neighborhood around the center and generally they already have skills because they have grown up among the environment of the center since their childhood. The labors that are close to the location also minimize the production costs. Physical resources describe the availability of production 
equipment required to support the development of wooden batik. Product sources describe the uniqueness of batik products. The wooden batik products of both centers have their own characteristics. The entrepreneurs in both centers have their own motives that are different from other entrepreneurs. The location describes the site of SMEs to the interested parties concerned, especially the consumers. Bobung batik center is located in ten kilometers from Wonosari City, but the access to the location is not passed by the public transport. The uphill road on the way to the studio of the center's members is also complicated for the consumers. Krebet Center is near the capital city of Yogyakarta, and the access to the location has been paved. Public transport also rarely passes through the road so that the consumers and tourists should ride the personal vehicles. Considering the location of the center is very important to facilitate the consumers and it becomes the major factor for the business continuity. Strategic location will attract the consumers. According to Frans (2003), a site or location will be very important to facilitate the customers in visiting because they will find the shortest distance.

The Demand Factor, the source of demand is the demand for wooden batik products produced by both centers. Demand for wooden batik generally comes from people around Yogyakarta area to send to out of the area and or abroad. Market development also illustrates the efforts of the entrepreneurs or artisans to improve the quality. Wooden batik centers of Bobung and Krebet have a variety of batik product innovations to adjust the market desires, ranging

Related industry factorsThe location of the supporting industries is related to the distance among the supporting industries with the SMEs. The location of the raw materials needed for the production of wooden batik comes from the center environment. The entrepreneurs plant trees used as the raw materials in the yard, but the materials are for the supply in fulfilling the demand of the entrepreneurs to supply the raw materials from Klaten, Banyumas, Bali and East Java. from household appliances, home decoration and souvenirs. The product quality is indicated by the suitability of the design specification. So a company has competitiveness if the company produces the quality products in accordance with the market needs (Muhardi, 2007).

Strategic factors of the company, company's strategy describes the strategy that run by an industry to win the competition. One of the strategies is promotion. Krebet center has a better online promotion strategy than Bobung center. The online media owned by Krebet center in the Krebet village web can be accessed at www.krebet.com., while Bobung center is still not actively doing promotion via online media. Sunarto (2004) stated that sales promotion encourages the spending or selling of the products and services, in which it covers a wide variety of promotional tools designed to stimulate the faster market response one of which is online media.

Government Factor, the human resource development is conducted in the form of design training and entrepreneurial motivation. The artisans and entrepreneurs who are the members of the center have participated in training organized by the Department of Cooperatives and Industry. This training is held regularly and alternately by every businessman. One of the training provided is the ability in improving the production technology and marketing. One technology in the production process is the dryers that are given by Department of Industry and Trade to Bobung center. The exhibitions are held in the province of DIY and outside the region and abroad.

\section{CONCLUSION}

. The formulation of alternative strategy using IE matrix on the Micro Small Medium Enterprises existing in the wooden batik craft center of Bobung and Krebet is in the position of quadrant I with the best strategy applied that is the growth strategy. Based on the SWOT quadrant, a position in quadrant I means that it is in an aggressive position, and the right strategy in this position is the Growth Oriented Strategy. Based on the quadrant of position I, the 
alternative strategy according to the SWOT table is the S-O (Strength-Opportunities) strategy by utilizing the strengths of the wooden batik center to seize the opportunities, with market development and product innovation.

The suggestions that can be given to the wooden batik handicraft center of Bobung and Krebet is: The efforts to increase the competitiveness in the wooden batik handicraft center of Bobung can be more maximized by reactivating the community of handicraft entrepreneurs with the wooden batik craft center of Krebet, the wooden batik handicraft festival can be used as a routine agenda in Bobung center as well as those in Krebet, the problem of both centers is the access to the location that is not passed by the public transport, so the government should provide transportation that reaches both villages, the entrepreneurs can utilize the existing technology currently for the online promotion media in order to expand the market share outside the Province of DIY, the Government (the Regional Development Planning Board, the Department of Cooperatives, the SMEs, the Department of Industry and Trade, DIY Provincial Government), the educational institutions, the entrepreneurs and communities can work together in attracting the productive youth's interest to preserve their culture. So they will not leave the area to find job.

\section{REFERENCES}

Anonim. 2008. Undang-undang No 20 Tahun 2008 tentang Usaha Mikro Kecil dan Menengah. Website http://www.scribd.com/doc/5029088/UUNo20-Tahun-2008. (Diunduh tanggah 19 Maret 2016)

Bonita,Farah (2013). Strategi Pengembangan Industri Kecil Kerajinan Batik Di Kota Semarang. Economics Development Analysis Journal, 2(3). doi:10.15294/edaj.v2i3.1978

David, FR. 2008. Manajemen Strategis Konsep. Edisi Ketujuh Bahasa Indonesia. Jakarta: PT Indeks.

Depbudpar.2014. Neraca Satelit Pariwisata Nasional (Nesparnas) 2014. Pusat Pengelolaan Data dan Sistem Jaringan. Jakarta.

Franzoni, Simona. 2015. Measuring the Sustainability Peformance of the Tourism Sector. Tourism
Management Perspective, Volume 16, Pages 2227.

Hunger, J.David \& Thomas L. Wheelen. 2003. Manajemen Strategis. Terjemahan Julianto Agung Edisi Kedua Bahasa Indonesia. Yogyakarta: Andi

Imam, Hariyadi.2003.Pengelolaan Kredit Mikro Melalui Program Pemberdayaan Ekonomi Keluarga. BKKBN

Irawan dan M. Suparmoko. 2002.Ekonomika Pembangunan. Yogyakarta: BPFE UGM

Michailidou, Alexandra V, et al. 2016. Interactions between Climate Change and teh Tourism Sector: Multiple-Criteria Decision Analysis to Asses Mitigation and Adaption Options in Tourism Areas. Tourism Management, Volume 55, Pages 1-12.

Muhardi. 2007. Strategi Operasi: Untuk Keunggulan Bersaing. Yogyakarta: Graha Ilmu

Rangkuti, F. 2005. Analisis SWOT Teknik Membedah Kasus Bisnis. Cetakan Keempat belas. Jakarta: Gramedia Pustaka Utama

Smecda. 2007. Kajian Efektifitas Model Pertumbuhan Klaster Bisnis UKM Berbasis Agribisnis. Diunduh pada tanggal 10 Mei 2016 pada pukul 20:00 WIB dari Http://Www.Smecda.Com/Kajian/Files/Hs lkajian/Kajian\%20efektifitas\%20model\%20pe numbuhan $\% 20 \mathrm{klaster} \% 20 \mathrm{bisnis} \% \mathrm{Ukm} / \mathrm{Bab} 2$ $\underline{\mathrm{Pdf}}$

Sugiyono. 2010. Metode Penelitian Bisnis: Pendekatan Kuantitatif, Kualitatif dan R\&D. Bandung: Alfabeta

Viren, Paige P, et al. 2015. Social Network Participation and Coverage by Tourism Industry Sector. Journal of Destination marketing and Management, Volume 4, Pages 110-119. 